\title{
The Poetry of Antiques: Trade and/in Knowledge among British Antiques Dealers
}

\author{
NICOLETTE MAKOVICKY \\ School of Interdisciplinary Area Studies \\ University of Oxford, Oxford, United Kingdom \\ nicolette.makovicky@area.ox.ac.uk
}

\begin{abstract}
This article considers the role of information, communication, and knowledge in processes of exchange and value creation in the British antiques market. As such, it positions itself between the long-standing anthropological interest in the cultural construction of value (see APPADURAI 1986; GRAEBER 2001), and the equally long-standing interest in how asymmetries of information affect consumer behaviour (see AKERLOF 1970). Drawing on ethnographic material gathered over three months of fieldwork amongst antique dealers in the Notting Hill and Kensington Area of London, I aim to through light on what it is that dealers 'know' and how this knowledge is translated into profit within the trade. I argue that dealers' knowledge of objects is encyclopaedic, discursive, and tactile at once and it is gained mainly through many years of handling of objects. Dealers must also keep abreast with the market movement of objects and their prices using this information to gage the potential profit they may accrue from a deal. Both forms of knowledge, I argue, are mobilized at once when a dealer is investing in stock and when he or she seeks to sell an item, in a ritual of show-and-tell that serves to both to verify the quality, condition and authenticity of a piece and to simultaneously negotiate its price.
\end{abstract}

KEY WORDS: antiques, antique dealers, knowledge, value, price, information asymmetry 
In Great Britain, long-running popular television serials such as Cash in the Attic and Flog It ! show individuals or teams of amateur antique dealers competing to earn the largest profit by purchasing inexpensive items in antique shops and selling them at small, rural auctions. However, while conducting fieldwork amongst established antique dealers in the West London area ${ }^{1}$, I found these programmes were highly criticized by for portraying the antiques business as an easy way of making an income requiring little investment of time and money. The dealers I spoke to, wanted the public to identify and respect them as experts with a great deal of specialist knowledge and superior aesthetic taste. They widely praised another programme: The Antiques Roadshow which showed members of the public bring in family heirlooms and personal positions for expert evaluation. Struggling with the public perception that dealing in antiques was a pain-free way of gaining an extra income, they felt this series was both educational and a more faithful portrayal of their professionalism. As one of my informants underlined, the ability to identify a valuable item and market it to the right client was not 'easy money' but required ' 35 years of knowledge'.

This article seeks to understand what it is that dealers actually 'know' and how this knowledge is translated into profit within the trade. The existing literature portrays dealers as 'knowledgeable specialists' who 'translate commodities into valuables', (JARVENPA 2003:556; FREUND 1995, PALMER - FORSYTH 2002). Dealers are understood to use their knowledge to commoditize inalienable possessions as antiques, thereby creating new classes of valuables from objects previously deemed to have little commercial value. Accordingly, scholars in the field of retail studies and marketing have focussed their attention to the way dealers construct narratives of history, authenticity, and taste in order to market and sell their antiques to private clients (PARSONS 2007, 2010). Others, interested primarily in the cultural meaning of collecting, have highlighted the manner in which notions of provenance and patina are tied to the creation of social status and genealogy by both dealers and consumers of antiques (McCRACKEN 1990; DILWORTH 2003; HILLIS - PETIT 2006). Finally, scholars have underlined the sociability of dealing, underlining that as much as the prospect of turning a profit, dealers enjoy 'the

1 This fieldwork was conducted from June to September 2007 as part of the project 'A Pilot Study of Interactions, Interconnections and Change in the Antiques, Car Boot Sale and Collectable Trades', funded by the Nuffield Foundation (SG-34304). The project was co-researched by Professor Daniel Miller, Professor Gerald Mars, Dr. Valerie Mars and Dr. Angela Burr. 
action associated with the hunt for bargains and treasures, and the bartering, bantering, and gaming that goes with the commerce of bargaining, selling, and collecting' (PALMER FORSYRH 2006:236). Yet, while highlighting the commercial importance of their knowledge of objects and their market, scholars have so far avoided any attempt to characterize this knowledge, noting that much of what dealers know remains 'tacit' or 'working' knowledge accrued through years of experience (ROSTER - ROGER 2016).

Drawing on ethnographic material gathered over three months of fieldwork amongst antique dealers in the Notting Hill and Kensington Area of London, I aim to provide a first insight into the nature of this knowledge. I argue that dealers' knowledge of objects is encyclopaedic, discursive, and tactile at once and it is gained mainly through many years of handling of objects. Best described as a kind 'poetry of antiques', it is seen as reflected in the nature and quality of their stock - it is a knowledge of objects, but also a knowledge in objects. Furthermore, I argue that the professional success of a dealer rests on his or her ability to embody the role of 'knowledgeable specialist' through the demonstration of this knowledge to colleagues and clients. The 'poetry of antiques' thus constitutes not only a form of knowledge, but also a language of distinction the mastery of which is crucial to dealer's ability to engage in commercially profitable exchanges. Dealers must also keep abreast with the market movement of objects and their prices using this information to gage the potential profit they may accrue from a deal. In contrast to their knowledge of objects (which must be publicly demonstrated and affirmed), dealers keep information about their sources, restorers, and the price and trade pedigree of their wares a secret. Both forms of knowledge, I argue, are mobilized at once when a dealer is investing in stock and when he or she seeks to sell an item, in a ritual of show-and-tell that serves to both to verify the quality, condition and authenticity of a piece and to simultaneously negotiate its price.

\section{Literature, Approach, and Method}

The British market for antiques is complex and (in parts) fairly poorly regulated. Across the country, antique dealers source, display and sell their stock in retail spaces that are often geographically and socially marginal to mainstream retail, such as car boot sales, markets, 
periodic fairs, antique centres, provincial auctions, and a network of fellow dealers. The existing literature on the collectables and antiques ${ }^{2}$ trade reflects this heterogeneity, presenting car boots, modest dealerships, and rural auctions as social and cultural events visited by professional dealers, collector-dealers, and tourists (BLEED 2000; JARVENPA 2003; PALMER - FORSYTH 2002, 2006). Together with research on garage sales, flea markets, and charity shops, these studies have shown how the exchange of second-hand goods subvert and redefine rules of exchange found in mainstream commercial retail (CREWE - GREGSON - BROOKS 2002, GREGSON - CREWE 1994, 1997a, 1997b, 1998, 2003). Participation in these forms of exchange is grounded in the exercise of practical, skilled knowledge, as well as the deployment and display of elite or specialist tastes. Indeed, due to the complexity of the market, traders use these discourses to construct a community of trades and clients on whom they rely on for sourcing, authenticating, and retailing their goods (ROSTER - ROGERS 2016).

Describing primarily on the lower end of the market, this body of work focuses primarily on processes of value creation. Following Arjun Appadurai's (1986) characterization of auctions as 'tournaments of value', many studies concentrate on illuminating and understanding the theatrical and performative nature of auction behaviour for the construction of price (GEISMAR 2001; SHERRY 2001; PALMER - FORSYTH 2006; HEATH LUFF 2007). Consequently, they approach questions of value and value creation following Charles Smith's assertion that value 'represents the collective judgement of the auction community' (SMITH 1989:77). While a critique of Smith's approach can be found elsewhere (GEISMAR 2001), this bias towards auction sales in the ethnographic material has led to the general understanding of value creation as outcome of the commoditization of objects through auction. Consequently, many studies have concentrated on the way auction goods are discovered, sourced, and then circulated through the auction process. Peter Bleed (2000), for example, describes a four-stage process by which objects are directed into the market as 'antiques': surfacing, picking, dealing, and matchmaking. They often operate with a corresponding 'ideal type' model of the trade, describing flea markets, antique centres, shops, and auction houses as 'geographically nested hierarchies'

2 The boundary between 'antique' and merely 'collectable', as well as the definition of the category 'antiques', is negotiated and re-negotiated by dealers over time. For the purpose of this paper, however, the definition of antiques is an item older than 100 years, while collectables are understood as (mass produced) mid to late $20^{\text {th }}$ century items.

DOI: 10.2478/eas-2018-0002 @ University of SS. Cyril and Methodius in Trnava. All rights reserved. 
(JARVENPA 2003) where artefacts are sold and resold, moving 'up' through multiple levels of dealers and gaining correspondingly higher prices with each resale (e.g. HERRMAN 1997, PALMER - FORSYTH 2002, 2006; SHERRY 1990). Assuming that this movement is down to the market desirability of the object, however, few have asked how and why objects continue to circulate this way.

In contrast, this article draws on ethnographic material from the medium to high end of the British Antiques market ${ }^{3}$, and aims precisely to shed light on the dynamics of dealer to dealer trade. Rather than adopting the object-focused, biographical approach (KOPYTOFF 1986) which dominates the above literature, I examine the conditions and dynamics of exchange itself. I show that the trade of quality antiques and their movement between dealers was not simply driven by their increasing expert knowledge as the 'ideal type' model implies. In line with recent work by Roster and Rogers (2016), my ethnography reveals that there is a relationship between the differential distribution of 'expert knowledge' amongst antique dealers their ability to turn profit. The market in which dealers operate is fundamentally disorganized and opaque; it 'includes non-traditional sources of goods, loosely connected channel members, and largely unregulated transactions between buyers and sellers' (ROSTER - ROGERS 2016:2). Roster and Rogers argue that operating in such a market brings with it a certain risk, but also allows experienced dealers to exploit asymmetries of knowledge and information to make substantial profits. In such a market, in short, knowledge of objects and of the market itself is a source of power which can be used to achieve a competitive advantage (ibid: 2). Indeed, in my West London field site, dealers actively maintained and reproduced such asymmetries through their management of ignorance on the part of their buyer or seller.

From analytical point of view, then, it seems useful to understand the market for antiques not simply as a series of 'nested hierarchies' defined by the increasing specialist knowledge, but as a 'bazaar economy' (GEERTZ 1978). Anthropologist Clifford Geertz has suggested that the bazaar could be seen as a particular kind of economy - an analytical idea, as much as a particular institution - which functions on the perpetuation of 'known ignorances' (GEERTZ 1978:29, emphasis in the original). Geertz identifies the state of low information saturation as the organisational principle of the bazaar. In the bazaar, Geertz

3 The price of my informants' stock ranged from the $£ 1000-3000$ range for china up to $£ 80000$ for the best items of furniture.

DOI: 10.2478/eas-2018-0002 C University of SS. Cyril and Methodius in Trnava. All rights reserved. 
argues, both buyers and sellers share a high level of ignorance about everything from product quality to the ongoing negotiation of prices. Business practice is thus largely determined by the search for information one lacks and the protection of the information one has. The desire to know what is really occurring, Geertz writes, is matched with the desire to deal with people who don't but imagine that they do. In short, Geertz identifies the state of low information saturation as the organisational principle of the bazaar. Over and above similarities between the institution of the bazaar and the antiques trade - the tendency for dealers of one class of object to congregate geographically, the tendency for an individual to occupy both buyer and seller roles, the ubiquity of bargaining and haggling at the time of sale, and the tendency to establish stable trade relations with other dealers and clients - the dynamics of the antiques trade shares with the bazaar economy this state of information shortage.

Using Geertz's notions of the 'bazaar economy' to guide my analysis of the ethnographic material, I start this article with a brief introduction to the field site and informants. I show how the dealers I spoke to faced both cyclical challenges which affected their ability to source and sell their goods, comparing the current state of the market unfavourably with the 'ideal type' model, which they took to be the norm. I then move on to consider the way in which they described and deploy their knowledge of objects (the 'poetry of antiques') in order to source their goods from fellow traders, verify their authenticity and worth, and sell them on to fellow dealers. In a community where professionals operated both as trusted colleagues and commercial rivals, I argue, the public demonstration of such knowledge is vital for their public affirmation as 'knowledgeable specialists'. Finally, I turn to consider the ways in which dealers mobilized both knowledge of objects and of the market to secure a profit on the sale of their stock. Perhaps most revealingly, I show how they felt threatened by the increasing use of online platforms by auction houses to advertise and sell antiques, as well as the proliferation of online prices indexes. Such online resources, they maintained led to increasing transparency and an 'overexposure' of stock rendering it less valuable.

This research is based on three months of ethnographic fieldwork (June to September 2007) amongst antiques dealers working from Kensington Church Street and the Portobello Road Market in West-Central London. Thirteen semi-formal interviews were conducted with dealers of European and Oriental china, furniture, prints, silver, and antique watches, as well as 2 interviews with executives at the London auction houses Bonhams and Sotheby's. Over the fieldwork period, I regularly attended auctions at 
Bonhams, Sotheby's, and Christies, as well as Portobello Market days. I also attended that year's Summer Art \& Antiques Fair at the Olympia exhibition ground, London. The antiques market is a relatively closed world in which market knowledge and business practices are rarely shared between market actors, and even less is revealed to outsiders (indeed, some dealers and the auction house Christies declined to participate in the research project). Hence, it often took a good deal of work on my part to convince informants to grant me an interview, and to open up about their businesses. Observation of non-verbal practices and interactions between dealers thus became important for gaining ethnographic insight into the trade.

\section{The Antiques "Food Chain"}

At 6 am on the last day of July in 2007, I made my way down Portobello Road from the Ladbroke Grove end up towards Notting Hill Gate. A Kensington Church Street dealer who I shall call James recommended me to visit the market at day-break. According to James, who started out selling antiques and bric-a-brac at Portobello Market some 36 years ago, a serious dealer will arrive well before 8am: the best deals are done between 6:30 and 7, even before stall-holders have unpacked. James recounted stories of struggles between dealers over good finds and hurried deals done by torchlight on early winter mornings. However, as I strolled up Portobello, past the still shuttered cafes and shops, the only sign of life were the vegetable and fruit sellers who were setting up their stalls. Indeed, the first stirrings of life in the antiques section of the market came just after $7 \mathrm{am}$. The arcades were unlocked and dealers started to arrive to open up their stalls. Boxes of prints were perched on chairs, textile dealers hung tablecloths and nightdresses and dealers in glass, Meissen and Rosenthal ceramics dusted off their wares and re-arranged them to make space for new items. Clutching cups of coffee, stallholders greeted each other and walked about, showing each other little 'finds' they had made during the week. A pair of golden earrings picked up for $f 5$ was shown by one man to a jewellery dealer for confirmation and authentication, another man came to the stall of a fellow dealer who showed off a carved ivory case which he had bought at an auction outside London.

According to James, the dealers of Portobello Road were the 'bottom feeders' of the antiques 'food-chain', hoovering up bargains at car-boot sales, village halls, rural auctions, and house-clearings and bringing them in to London to sell for profit. These traders were just one step up from 'totters' who bought anything from scrap iron to old furniture, or 
'knockers', that is traders who knocked on peoples' door asking whether they had anything they wanted to be rid of. Portobello Market, then, was one of the entry points for antiques and collectables into the London trade. Canvassing the market, I met dealers who drove down from the Midlands, or up from South-East England, or even from as far as Paris every Saturday to sit in their stalls from 7 am to 4 pm. Of the approximately 1000 that traders rented the stalls and street-stalls for the Saturday market-day, more than half were 'part-time' dealers. 'Part-time dealers' were often persons who have jobs in related fields, such as in the auction business or as museum curators. 'Full-time' dealers may have had shops outside of London or supplement their face-to-face sales by selling on Ebay and other auction websites. Yet, while there was a certain amount of catching up on gossip and socializing, I saw little actual dealing done amongst the stall-holders. The bazaar or wild-west atmosphere I had been led to imagine existed was not there. Perhaps I had missed something? Or perhaps dealing was simply done so discreetly that without knowing the rules of the game, a visitor wouldn't even notice?

A week later, I returned to Kensington Church Street to revisit James in his shop. I recounted my experiences of visiting Portobello Market and he then told me that he had not purchased anything from the dealers in Portobello for more than a decade: according to him, there were no more good deals to be had on the market. Angela, a dealer in 18th century Continental china with a shop further down the street, echoed James's evaluation. In the late 1970s, while she was working full-time at a London auction house, Angela had rented a stall and sold china at the market on Saturdays. However, while she still liked to go to the market to socialize, she said there was little in the way of quality ceramics. If the dealers of the Portobello Road Market were the 'bottom feeders' of the antiques 'food chain', then, the dealers on Kensington Church Street were somewhere near the top. Over 60 dealers worked on or just off Kensington Church Street during the period of my field work, the majority from shops and showrooms, dealing in everything from oriental arts, English and continental furniture, walking sticks, books, glass, silver, porcelain and 20th century oil-paintings. My respondents, James and Angela amongst them, had been in the business for at least 20 years, some of them for more than 30 years. However, only James and Angela have spent the majority of their careers dealing from the street, the rest had moved into the area only within the last five years.

One newcomer to the area, of not the trade, was Oliver who traded in 17th, 18th and 19th century furniture. When I visited his shop, Oliver happily showed me his stock, his private collection of antique tea-caddies and even gave me a lecture on the history furniture 
design. Passionately attached to his stock, Oliver told me that the 'joy of the kit is what it is made of' - in other words, he loved wood. As we went around his shop, he spoke about the various pieces he had on sale and why he liked them. He pointed to inlaid details on tables and sideboards, explaining the different properties of various kinds of wood. Oliver hated the common description of historical furnishings as 'brown furniture', and made it clear to me that he was not just a 'brown furniture dealer'. 'Brown furniture', to him, was boring furniture, but there was something special about each of his items. While I was talking to Oliver, he got a visit from a 'runner'. 'Runners' are dealers who work exclusively as middlemen, selling their finds to more retail oriented colleagues with a shop front or a showroom. In this case, a man rang on the shop's doorbell and called Oliver out to his car, saying he had something to show him. A few minutes later, Oliver returned to the shop beaming, carrying an early 19th century toddler's chair. After some joking around, he made out a cheque of an undisclosed amount to the man. Oliver was extremely pleased with his purchase and spent the next 15 minutes showing me the chair and its various accessories with pride.

Despite his enthusiasm and his purchase, Oliver later described his business as a 'constipated cow': it was being filled with valuable stock, but things were not shifting. Something had to give - either he had to rid himself of some stock or buy another premises to house the overspill. While the antiques trade had been through its ups and downs since he entered it in the late 1960s, Oliver claimed that it was only now that fashion was beginning to have an adverse effect on the demand of antique furniture. He blamed the continuing popularity of modernist aesthetics for putting the next generation of moneyed individuals off antiques. While owning antique furniture had once been an aspiration for the middle and upper-middle classes, such furniture was no longer status symbol. The number of customers had fallen in the past few years, Oliver told me, and many dealers were on the brink of losing their shops or even their livelihood.

Oliver's concerns were echoed by another furniture dealer working from Kensington Church Street, Mark, who described the trade in furniture and antiques in general as being in a state of crisis. Mark lamented that good quality objects have become harder to find. According to Mark, the 1960s and 1970s had been a time of 'plentiful' and 'cheap' goods. Many unwanted furnishings emerged from house clearances and the demolition of scores of Victorian homes. At the time, many dealers refused to deal with members of the public who came searching for specific items, preferring to deal in bulk within the trade. Some dealers did not even bother to trade locally or nationally, but shipped container loads of 
furniture to the hungry North American market. Today, Mark told me, the situation had changed completely. He reckoned that $90 \%$ of all 'ordinary' antiques would never find a buyer. He reasoned that this was partly due to the fact that the dollar lost its strength against the pound, leading to a drop in demand from the North American market. However, he also remarked that there had been a shift in the market towards the higher end - customers were becoming more knowledgeable and discerning. Mark told me that he himself had had to 're-invent himself as a retailer'. While today the majority of his clients were wealthy Russians, Americans, and the 'odd oil wealth', only ten years ago the majority of his sales had been made to other dealers.

Mark's description of the contemporary state of the trade as characterized by increased competition for a small pool of high quality items at the top of the market and a larger pool of un-saleable items circulating at the bottom of the market, was one I heard from almost all the antique dealers I spoke to - regardless of their specialization. Commonly they referred to this as a 'polarization' of the market and the disappearance of the 'middle market'; that is, the loss of a certain category of customer (the aspirational middle and upper-middle class), but also the corresponding loss of a category of stock ('ordinary' antiques) and a category of trade (runners and wholesale, inter-trade dealers). While certain dealers used the slightly more loaded word 'consolidation' to describe the market implying that successful, knowledgeable dealers had out-competed their less able colleagues - common to all interpretations of the state of the trade was that the 'foodchain' was no longer complete or functioning. Curiously, my interviews revealed that the pessimism which this comparison elicited was actually a persistent feature of the trade: Mark told me that at the time he started dealing in the late 1960s other dealers tried to put him off joining the business because there was 'no more Queen Anne', only Georgian furnishings. Indeed, one dealer with a premises on Portobello Road recalled that when her father had started working as a silver dealer in the 1920s, more experienced dealers regularly complained that there was 'nothing to sell'.

Thus, while the problems facing dealers are very real, their perception of the state of the trade appeared to reflect both their momentary position in their career and the fluctuations caused by wider economic cycles. The oft repeated perception that quality items have become increasingly scarce, for example, could have been determined by the continual shifts in demand inherent in the antique trade's own fashion cycles, as well as changing tastes in interior decoration. However, it may also quite simply have been a function of the career path of the individual dealer: more experience and a higher degree 
of specialization led dealers to place higher criteria on the stock they were prepared to invest in. In fact, as we shall see below, the knowledge and reputation of a dealer were seen as being quite literally objectified in the quality of their stock, leading dealers to engage in elaborate, public rituals of exhibiting and vetting.

\section{The 'Poetry' of Antiques}

Antique dealers are often said to be collectors who turn to selling antiques to fund their own purchases. For some of my respondents, it was indeed a passion for the items that they sold which had brought them into the business. In other cases, it was a passion for the business of trading itself. This was the case for Andrew, who rents a stall selling prints on the Portobello Market. Andrew started dealing after leaving university. He told me that his mother had been working as a receptionist at an art dealership at the time and it was a client at this dealership who gave him his first break by giving him some paintings to sell. Andrew admitted that at the time he had had no idea what they could be worth and sold them all for between $£ 20$ and $£ 80$. Not only did this small profit end up being his start capital, but he 'got a taste' for the business. Starting out as a dealer, however, had been difficult. Not only did he have relatively little capital in the first years, but Andrew also lacked adequate knowledge. His first investment was a job lot of prints from Bonhams for f130. He explained that this is how he got most of his stock in the first years - by going to auctions and picking up the lower end of the lots. Eventually, he found other sources as he gained more experience and more capital. The good deals he had made were usually when he picked up items from other dealers who 'did not know what they had'. Andrew got a stall at Alfie's Antique Market in Marleybone in the early 1980s. Today he has a stall at the Portobello Market, but sells the majority of his prints on the Internet. In fact, he told me that his Saturday stints at the market are pure 'entertainment' and almost negligible in terms of the income they generate.

Andrew's description of the challenges facing a budding dealer who still lacks sufficient capital and knowledge, was echoed by many of my other respondents. As Roster and Rogers note, the disorganized nature of the antiques market can be perilous for inexperienced dealers as 'as unknowledgeable participants can become easy prey for unscrupulous market players eager to take advantage of new entrants' (ROSTER - ROGERS 2016:6). Like Andrew, my informants reported that they started out dealing with small, 
The Poetry of Antiques: Trade and/in Knowledge among British Antiques Dealers

relatively inexpensive items and working their way up to establish themselves as independent traders in the community. A few came from a family tradition of antiques dealing. Regardless of whether they came from a family of dealers or fell into dealing more or less by chance, however, they consistently told me that one learned by handling objects, reading the relevant literature, watching, listening and, James told me, by 'making mistakes'. As one silver dealer working just off Kensington Church Street told me, he had built his reputation and his business as through ' 30 years of osmosis'. He dismissed the notion that an art or art history degree could substitute the hands-on experience that novice dealers gain through buying, selling and handling objects. He told me that the type of knowledge a dealer has of objects is not comparable to any sort of science, but more a kind of 'poetry'.

The necessity of handling a large amount of objects was echoed by Angela and Oliver, who were both trained at of the major London auction houses. One of the advantages of starting out as a porter in a salesroom, they told me, was the high turnover of different objects. As Oliver put it: 'Eventually you shed your overalls, become a knowledgeable assistant and then an expert. There is a point in your apprenticeship when you start buying things with your own money and dealing with them. You develop a style'. Apart from encyclopaedic knowledge of materials, styles, and the art of restoration, in other words, the taste and preferences of a good dealer was understood as reflected in his or her stock. Dealers working from Kensington Church Street or at the Portobello Market alike would often lecture me on the importance of having what they called 'the eye' for objects. Having 'the eye' was likened to having an innate sense of beauty or good taste, which could not inculcated through experience or formal schooling. Just like a dealer's encyclopaedic knowledge, their 'eye' is demonstrated in their choice and display of stock. Oliver described his 'look' as 'good and interesting furniture', thereby underlining his previous assertion that each of his pieces was 'special'. A dealer's specialist knowledge, then, was a knowledge of objects but also knowledge in objects.

Indeed, the degree to which specialist knowledge was seen as completely intertwined with actual objects was the emphasis put on the quality of a dealer's stock as a measure of their professional expertise and reputation. Vetting - the inspection and evaluation of stock by a select committee of established dealers - is common practice at antique fairs, where the quality and authenticity of stock presented at each stall is monitored. It is also an established part of the interview process for membership of the major trade associations the British Antique Dealers Association and LAPADA (The Association of Art 
and Antique Dealers), as for local associations such as the Portobello Antique Dealers Association and the Kensington Church Street Antique Dealers Association. The BADA, for example, demands 'evidence that the applicant possesses or commands the degree of knowledge required to enable the applicant to buy and when selling to describe the antique goods of the kind in which the applicant deals' ${ }^{4}$ and this evidence is gathered by three assessors who visit the applicant's premises inspect the stock, discuss it with the applicant and evaluate the shop layout. Mistakes, mislabelling, 'married' pieces 5 and pieces deemed to be inappropriately restored were all clear indications of a dealer's lack of knowledge or integrity. Yet, the emphasis put on 'description' by the BADA suggests that dealers view narration as a key component of the professional practice. Mark, of Kensington Church Street, told me that knowledge is about subtlety, it is about noticing and revealing the details only a trained eye can see. Vetting is effectively a game of show and tell, where not only the object itself is evaluated, but the dealer's ability to explain and expand upon what is immediately visible. In this way, the silver dealer's characterization of an antique dealer's knowledge of objects as a type of 'poetry' appears quite accurate: knowledge appears to not simply be perceived as objectified in a dealer's stock, but as arising from a dialectic between the material and the narrative.

As my early morning forays into the Portobello Market showed, such vetting practices are simply a formalized version of much of the social exchange that dealers engage in on an everyday basis. Dealers regularly refer to each other for advice and help, drop by to admire another's recent acquisitions and discuss interesting pieces with each other. In this respect, the social interaction between dealers is similar to that found by Louise Crewe et al. (2003) amongst retailers of retro clothing, furnishing and décor. Crewe and her coauthors illustrate how this group of retailers engages in 'celebratory talk' that counterposes their own commercial practice as part of a creative alternative to the imagined homogeneity of conventional retail. Retro retailers have a 'perceived need to talk in certain socially approved ways about their work', celebrating 'the creative over the commercial, the aesthetic over the economic' (CREWE et al. 2003:66). Retailers speak of their stock in reverent and loving tones, emphasizing their intrinsic design qualities, beauty and aesthetic superiority, a discourse shared by antique dealers - much like Oliver,

$4 \quad$ British Antique Dealers' Association Bye-laws (http://www.bada.org/metadot/index.pl?id=2190

5 A 'married' piece of furniture is one in which the top and bottom are from different original pieces.

DOI: 10.2478/eas-2018-0002

(c) University of SS. Cyril and Methodius in Trnava. All rights reserved. 
who clearly is very attached to his 'kit'. The 'poetry' of antiques can be compared to the 'fetishized commodity talk' (CREWE et al. 2003:68) of retro-clothing sellers, a language of distinction that is used as much to demonstrate a trader's cultural capital, as it is used to convey information about the object. Through such discourse, dealers no only make the distinction between themselves as expert tastemakers and the general public, but within their own profession. Indeed, the exclusivity of the major trade associations is testament to the internal hierarchy that exists between dealers, a hierarchy that is created and maintained through practices of vetting and networking.

In short, the appreciation of antiques requires a form of knowledge that is encyclopaedic, discursive and tactile all at once; and the demonstration of this knowledge is important for the establishment of a dealer's credentials as a competent judge of tastes, quality, and value. The importance of the 'poetry of antiques' as a language of distinction, however, should not be allowed to overshadow the fact that dealers use their senses to know and learn. Dealers constantly touch and handle objects, inspecting their veneers and imperfections - especially if they are considering investing in a particular item. The day I had first came to interview James, our conversation was interrupted the appearance of a client - a middle-aged, Chinese gentleman. It was clear from the way James greeted him, that they knew each other. I could hear them speaking in quiet voices in the shop, James showing him his recent acquisitions and taking them out of the cabinets. There was a series of 'plink' sounds as the man tested the vases and other objects for cracks. James brought a small flashlight from the back office into the shop. Several times the man brought items to the large window in the back office, turning them upside down and checking the mark and bottom surface. He handled everything from small saucers and dishes to vases. Eventually, he settled for two large vases. In hushed voices, he and James agreed on a price and the two vases were wrapped up in several layers of bubble wrap and placed in a large cardboard box, which the man carried away after handing James a check. James told me that this gentleman buys from him approximately every two weeks. He then exports the ceramics to Beijing. However, James is not exactly sure whether he acts as an agent, sells his items at auction, or whether he is simply supplying his own Beijing store. He has never said, and James has never asked.

In the case of dealer-to-dealer trades I observed, then, the handling and discussing items that constitutes the 'poetry' of the object was not just an important part of the exchange, but the very basis of any sale. As well as a demonstration of connoisseurship, the handling and discussing of objects invited the buyer to verify the quality of the object they were 
being offered and the correctness of the information they had received about it. Thus, these conversations were not simply a 'sales pitch' aimed at making the item attractive to the customer, but more the confirmation of shared knowledge about the object (and thus, the establishment of trust between the buyer and seller). Indeed, in all cases deals were done between partners who were already well acquainted with each other. Thus, while the price of an antique may be determined at the moment of exchange, deals such as the one done between James and his Chinese associate, or Oliver and the runner offering him the toddler's chair, happen in an environment where value-creating banter is the norm. Speaking the 'poetry' of antiques was not only a way through which dealers performed their identity as 'knowledgeable experts'; it was also a value-creating endeavour: demonstrating their specialist knowledge by elaborating verbally on the material and visual characteristics of the object, dealers simultaneously construct the object as authentic, unique, and of a high value.

Yet, the case of James and his Chinese client also shows that a good working relationship amongst dealers can at times be based on not asking too many questions. Although a sale between dealers was based on the mutual confirmation of shared knowledge about the object in question, there was a class of information that is neither shared nor made public. Price, then, was constructed as much through the manipulation of ignorance, as through the exchange of facts and observations. As I demonstrate in the following, knowledge about the source of an object, its trade history and restoration was central to the construction of value as price, but crucially it remained outside the remit of the 'poetry of antiques'.

\section{The Price of Information}

Martin, a dealer in antique clocks, told me that the three most important assets a dealer had was the source of his goods, a good restorer and solid, specialist knowledge. While demonstrating their expertise may have been an integral part of commercial exchange and professional attitude, the identity of a dealer's favoured restorer and their sources are both taboo subjects. Martin told me that dealers did not reveal to each other which restorers they have on their books, although they will arrange for another dealer's object to be restored with them. Echoing him, James told me that dealers 'keep their sources quiet'. Joanne, a specialist in antiques textiles who put a lot of emphasis on the mutual 
help between dealers at the Portobello Road Market, put it like this: 'You've got to have a balance...certain things you have to hold back. On the other hand, we try to help each other. Or...but...to some extent if they ask me 'what is this?' I am a little bit careful. I tell them the basics, but if you go into too much detail, you're giving away your livelihood'. Thus, while objects were offered up for inspection, discussed and elaborated upon in order for their quality and value to be confirmed by colleagues and clients, the origins and trade pedigree of an object were things which ideally remained a mystery. Dealers sought as much as possible to conceal the source of their stock, fearing not only that their clients may bypass them and go directly to the source in the future, but also that their stock may become 'burnt' through overexposure to the market.

Studying the antiques trade in rural up-state New York, Robert Jarvenpa (2003) noted that local dealers were often aware of the trade pedigree of finer antiques, attending auction to collectively 'observe its movement onwards' in the market (JARVENPA 2003:573). Amongst the dealers of the West London antiques scene, however, there appeared to be no such notion that objects accrued value through the public exposition of their dealer pedigree $^{6}$. Rather, as Angela told me, in order to get an optimal something, it was vital to make sure it has not been seen by anyone else in the trade before: an object going into a trade show or an auction had to have the appearance of being 'completely fresh'. In fact, Angela regarded the degree of exposure an item enjoyed as conversely related to the price it might attain. A rule of thumb, she said, was that $1 / 3$ of the stock would be 'whisked out of the shop', 1/3 had credibility and stood on the shelf for a while before it was sold, and $1 / 3$ was simply un-saleable. These items were taken to a country auction and sold at a loss. Angela was aware of the fact that her clients regarded her stock and her expert knowledge as intimately connected, and thus she avoided investing in a wellknown item or continually exhibiting the same items in public. Hanging onto stock that had proved unpopular may have sent the signal that she was unable to source the best specimens, thus damaging her reputation as a 'knowledgeable specialist'.

The need to keep information about the source, trade pedigree, and price history of an object was underlined by Joanne when I asked her whether she considered price and value the same thing. How important that information was, she said, depended on whether you

6 In fact, Geismar (2001) reports on how the trade pedigree of an object can actually devalue an object, if the previous owner does not enjoy the respect of his or her dealer colleagues.

DOI: 10.2478/eas-2018-0002 C University of SS. Cyril and Methodius in Trnava. All rights reserved. 
were buying or selling. At auctions, for example, objects are given an estimate in set price brackets. As a novice, Joanne had taken note of the auctioneer's estimates until an experienced colleague told her he never even looked at the estimates, but simply knew the market value from experience. The ability to recognise value as latent or potential price, then, depended not only upon expert knowledge of a class of object, but also a welldeveloped sense of the market value of items, appropriate sources and the correct venues for its sale. The value of such knowledge was most obvious when dealers discovered a 'sleeper' - that is, an item that had been undervalued, usually because of misidentification or ignorance on the part of the seller. As one dealer in Portobello Market put it: 'What you're always hoping for, when hunting about in Portobello Road in the early morning, for instance, is to find something on someone's stall that they don't know about, and hence have undervalued. The same goes for trying to get antiques at auctions. If they have been incorrectly valued in the catalogue, or wrongly identified, for example, then, with luck, you might be able to get them at a better price.' Good finds, then, were based as much on another's ignorance, as they were on dealers' own expertise.

The example of the 'sleeper' illustrates how the search for information, its exchange and concealment drives the antiques trade, and how information asymmetry can be turned into a competitive advantage by experienced dealers. Yet, while 'sleepers' are a relatively rare breed of antique, such good finds were not simply a perk or a bonus experienced occasionally by West London dealers. Rather, several dealers I talked to underlined the fact that finding such gems on a regular basis was quite simply an economic necessity for the longer-term viability of their business. With profits as low as $10 \%$ on most objects, dealers cherished 'sleepers' not only because of the thrill of their discovery, but because 'sleepers' constituted a much-needed cash injection into the business. Angela, who dealt in 18th century English china, told me that she did a lot of 'buying for 1 and selling for $1 \frac{1}{2}$ ' in order to earn her 'bread and butter'. James told me that with an average profit of between $10-20 \%$ on sales, he had to find a bargain every once and again in order to keep up with the overheads. Indeed, for dealers who bought and sold objects with a high market value, securing a 'good find' sometimes required the prior investment of a lot of time and effort, as well as money. One of Mark's good finds was an early 18th-century French bookcase that he not only had to fly to France to inspect, but ship to the United Kingdom in time for the Olympia Fine Art and Antiques Fair that year.

The ability of dealers to turn a profit by exploiting information asymmetries in the market, however, is increasingly coming under threat from the emergence of a number of trade 
magazines and newsletters, price guides, and use of the Internet for price indexes and tracking, advertising, online cataloguing and auctioning. ${ }^{7}$ The increasing availability of information on items and their history means that objects are increasingly becoming known and visible: Mark told me that 'runners' were now turning up at the shop offering him items which he had already seen at auction, in a catalogue, or on the internet. Most likely, he had already decided he did not want to invest in the item. Angela described the increasing transparency afforded by illustrated catalogues, virtual galleries, and search engines as a double-edged sword: on the one hand it meant that you usually have a better idea of what you were being offered, but so did everybody else. With increasing use of Internet bidding and professional catalogues, Mark commented, objects would 'find their price' in even 'the tiniest auction room'. Dealers feared that as the movement of objects and the prices they commanded became public knowledge, it would not only become harder and harder to find 'sleepers', but strategies such as Angela's habit of disposing of unsaleable items at rural auctions would no longer be enough to keep their reputations intact.

\section{Conclusions: Knowledge, value, and profit}

Seeking to understand what it is dealers 'know' and how they use this knowledge to make a living, this article has focused on the dynamics of inter-trade dealing and the creation of a trade-specific discourse I have called the 'poetry of antiques'. This 'poetry' is the verbalisation of a highly complex amalgamation of encyclopaedic, visual and tactile knowledge that dealers gain from specialist literature and years of handling objects, and is employed as a language of distinction through which dealers perform their identity as 'knowledgeable specialists' vis-à-vis other dealers and the general public. Indeed, knowledge appears to not simply be perceived as objectified in a dealer's stock, but as

7 Dealer's themselves feel they contribute to this flood of information on the market through their own advertising. For example, Mark, who deals in Kensington Church Street, has not only a website, but one can access his virtual gallery through the LAPADA, BADA and CINOA websites. $\mathrm{He}$ has researchers in several parts of the world (Continental Europe, US, South America) who spend time surfing the net and probing local dealer networks for him. In a way, he has hired himself 'runners'. In addition, Mark publishes an annual catalogue and several newsletters a year for his clients and participates in the three major London fairs (Olympia Winter/Summer, BADA Chelsea). 
arising from a dialectic between the material and the narrative. Successful dealers are in possession of not only object-oriented knowledge in their area of expertise, but also accrue knowledge about the market for these items - reliable sources, price histories, and profitable outlets. In contrast to the very public - even competitive - 'poetry of antiques', information about the source of an object, the restorer, its trade pedigree and price, is concealed by the seller. In short, the differential spread of expert knowledge about objects, but also information about the market, is crucial to trade dynamics and can act as an incentive or disincentive for dealers to buy. These two forms of knowledge are mobilized when a dealer is investing in stock and when he or she seeks to sell an item, in a ritual of show-and-tell that serves to verify the quality, condition and authenticity of a piece and negotiate its price. These negotiations, however, are also highly dependent on the management of ignorance on the part of the seller, either by concealing their source or investment, or by taking advantage of another's lack of specialist knowledge, as in the case of a 'sleeper'.

In short, my ethnographic material has shown the importance of knowledge, communication, and information - especially information asymmetry - for the functioning of the antiques market. This has led me to question certain assumptions present in previous studies of dealing and the antiques business. Firstly, I have shown how the ideal model of the antiques trade ('nested hierarchies' or the 'food-chain' model) appears to function as an unattainable norm against which dealers compare (negatively) their contemporary experience of the trade. Furthermore, I question the role of public affirmation for the creation of value. The auction has commonly been thought of as the entry point of objects into the trade and therefore a public forum for dealers present to evaluate and commodify inalienable objects. Indeed, ethnographies of the antique business have generally regarded value as created at auction through a moment of 'collective judgement' (SMITH 1989:77) or 'collective witnessing' (JARVENPA 2003:573) of their trade pedigree and price movement. Yet, as I have shown, antiques which are already in circulation and sold between dealers gain their value not only through successive moments of exchange, but through vetting practices and the language that is used to describe and talk about them. Indeed, while the 'poetry of antiques' can be seen as a form of value-creating banter, then it is important to note that what is being publicly affirmed is not the trade pedigree and price history of a particular item, but the quality and authenticity of a series of antiques of a particular class, as well as the reputation of the dealers handling them. 
Finally, the widely held perception amongst dealers that the market functioned best (and the biggest profits are made) when it remained opaque - and that the increasing transparency of the antiques market was harming the value of objects - revealed much about their concept of value. Firstly, dealers clearly differentiated between price and value as categories of worth. Thus, while auctions and sales created a price, the dealers I spoke to clearly differentiated between the auction price or purchase price and the price-tag which they themselves could put on the object - that is, the value. Their frequent claims that an object has an 'ultimate price' or 'found its price' revealed that dealers did not simply operated with a negotiable, open-ended concept of value (PALMER - FORSYTH 2002:181), but that value was conceived of as a potential to be realised through the skilled application of the dealers knowledge. Value, in other words, was an abstract and fixed notion of the maximal price tag that can be put on an item. The measure of a good dealer, then, was not only what he or she knew, but also how they used their specialist knowledge to realise the value potential of their stock - that is, the 'ultimate price'.

\section{Bibliography}

AKERLOF, G. A. (1970): The Market for "Lemons": Quality Uncertainty and the Market Mechanism. In: The Quarterly Journal of Economics, vol. 84(3), pp. 488-500.

APPADURAI, A. (1987): The Social Life of Things: Commodities in Cultural Perspective. Cambridge: Cambridge University Press.

BLEED, P. (2000): Purveying the past: Structure and strategy in the American antiques trade. In: Plains Anthropologist, vol. 45, pp. 179-188.

BISHOP, R. (1999): What Price History? Functions of narrative in Television Collectibles Shows. In: Journal of Popular Culture, vol. 33(3), pp. 147-162.

BISHOP, R. (2001): Dreams in the Line: A Day at the Antiques Roadshow. In: Journal of Popular Culture, vol. 35(1), pp. 195-209.

CREWE, L. - GREGSON, N. (1998): Tales of the unexpected: exploring car boot sales as marginal spaces of contemporary consumption. In: Transactions of the Institute British Geography NS, m 23, pp. 39-53. 
CREWE, L. - GREGSON, N. - BROOKS, K. (2003): The Discursivities of Difference: Retro retailers and the ambiguities of 'the alternative'. In: Journal of Consumer Culture, vol. 3(1), pp. 61-82.

DILWORTH, L. (2003): Acts of Possession: Collecting in America. New Brunswick, NJ: Rutgers University Press.

FREUND, T. (1995): Objects of Desire: The Lives of Antiques and Those Who Pursue Them. London: Penguin.

GEERTZ, C. (1978): The Bazaar Economy: Information and Search in Peasant Marketing. In: Economics and Anthropology, vol. 68(2), pp. 28-32.

GEISMAR, H. (2001) What's in a Price? An Ethnography of Tribal Art at Auction. In: Journal of Material Culture, Vol. 6(1), pp. 25-47.

GELL, A. (1998): Art and Agency: An Anthropological Theory. Oxford: Clarendon Press.

GRAEBER, D. (2001): Toward and Anthropology of Value. London: Palgrave McMillan

GREGSON, N. - CREWE, L. (1994): Beyond the high street and the mall: car boot fairs and the new geographies of consumption in the 1990s. In: Area, 26(3), pp. 261263.

GREGSON, N. - CREWE, L. (1997a): The bargain, the knowledge and the spectacle: making sense of consumption in the space of the car boot sale. In: Environment and Planning D: Society and Space, Vol. 15(1), pp. 87-112.

GREGSON, N. - CREWE, L. (1997b): Performance and Possession: Rethinking the Act of Purchase in the Light of the Car Boot Sale. In: Journal of Material Culture, Vol. 2(2), pp. 241-263.

GREGSON, N. - CREWE, L. (1998): Dusting down Second-hand Rose: gendered identities and the world of second-hand goods in the space of the car boot sale. In: Gender Place and Culture, Vol. 5(1), pp. 77-100.

GREGSON, N. - CREWE, L. (2003): Second Hand Cultures. Oxford: Berg.

GREGSON, N. - CREWE, L. - BROOKS, K. (2002): Discourse, displacement, and retail practice: some pointers from the charity retail project. In: Environment and Planning A, Vol. 34(9), pp. 1661-1683.

HEATH, C. - LUFF, P. (2007): Ordering competition: the interactional accomplishment of the sale of art and antiques at auction. In: The British Journal of Sociology, Vol. 58(1), pp. 63-85. 
HERRMAN, G. (1997): Gift or commodity: What changes hands in the U.S. garage sale? In: American Ethnologist, Vol. 24(4), pp. 910-930.

HILLIS, K. - PETIT, M. (2006): Everyday Ebay: Culture, Collecting, and Desire. London: Routledge.

JARVENPA, R. (2003): Collective Witnessing: Performance, Drama and Circulation of Valuables in the Rural Auction and Antiques Trade. In: Journal of Contemporary Ethnography, Vol. 23(5), pp. 555-591.

KOPYTOFF, I. (1987): The Cultural Biography of Things: Commoditization as Process. In: Arjun Appadurai (ed.): The Social Life of Things: Commodities in Cultural Perspective. Cambridge: Cambridge University Press, pp. 64-92.

McCRACKEN, G. (1990) 'Ever Dearer in Our Thoughts': Patina and the Representation of Status Before and After the Eighteenth Century. In: Culture and Consumption. Bloomington, In: Indiana University Press, pp. 31-34.

MILLER, D. (2000): The birth of value. In: Peter Jackson, Michelle Lowe, Daniel Miller Frank Mort (eds.): Commercial Cultures: Economies, practices, spaces. Oxford: Berg, pp.77-83.

PALMER, E. C. - FORSYTH, C. J. (2002): Dealers and Dealing in an Antique Mall. In: Sociological Spectrum 22, pp. 171-190.

PALMER, E. C. - FORSYTH, C. J. (2006): Antiques, Auctions, and Action: Interpreting and Creating Economic Value. In: The Journal of Popular Culture, Vol. 39(2), pp. 234259.

PARSONS, E. (2007): Dealing in Histories: Durability, Authenticity and Provenance in Markets for Antiques. In: European Advances in Consumer Research Volume 8. In: Stefania Borghini, Mary Ann McGrath, and Cele Otnes (eds.), Duluth, MN: Association for Consumer Research, pp. 111-112.

PARSON, L. (2010): Markets, identities and the discourses of antique dealing. In: Marketing Theory, Vol. 10(3), pp. 283-298.

ROSTER, C.A. - ROGERS, M.M. (2016): Profits and perils in the antiques and collectibles market: the influence of product knowledge structures on dealer exchange outcomes. In: The International Review of Retail, Distribution, and Consumer, vol. 26(1): 1-16.

SHERRY, J. F. (1990): A Sociocultural Analysis of a Midwestern American Flea Market. In: Journal of Consumer Research, vol. 17(1), pp 13-30.

SMITH, C. (1989): Auctions: The social construction of value. New York: Free Press. 